\title{
Diuretics and asthma
}

Sometimes novel treatments arise from chance observations made with existing drugs. The beneficial effects of an inhaled diuretic, frusemide (furosemide), in asthma challenge studies has raised the prospect that diuretics may have a role in the treatment of asthma in the future. ${ }^{1}$ These observations originate from the observation made by Bianco and colleagues that nebulised frusemide inhibited bronchoconstriction induced by exercise and by nebulised water in asthmatic patients. ${ }^{23}$ Since then the inhibitory effect of inhaled frusemide has been shown in a number of "indirect" challenges (which are thought to cause airway narrowing by releasing a bronchoconstrictor rather than via direct contraction of airway smooth muscle). These include bronchoconstriction induced by sodium metabisulphite, ${ }^{4}$ adenosine monophosphate, ${ }^{5}{ }^{6}$ hyperventilation, ${ }^{7}$ and the early response to inhaled allergen, ${ }^{89}$ in addition to exercise ${ }^{21011}$ and fog. ${ }^{31213}$ In this issue of Thorax Rodwell and colleagues describe a similar inhibitory effect of inhaled frusemide in hypertonic saline, another indirect challenge ( $p p$ 208-14). In contrast to the inhibitory effect on indirect challenges, inhaled frusemide has no protective effect in direct bronchoconstriction induced by histamine, methacholine, or prostaglandin $\mathrm{F}_{2 \alpha}{ }^{45 i 14}$ These in vivo studies are supported by studies showing that frusemide has no effect on contraction of airway smooth muscle in vitro even when airway epithelium is intact. ${ }^{1516}$ This profile of effects is very similar to that observed with sodium cromoglycate and nedocromil sodium, suggesting that these cromones may share a common mechanism of action with frusemide.

\section{Mechanism of action}

The mechanism of action of inhaled frusemide in indirect challenge is still not clear but several clues are provided by recent investigations. Frusemide acts as a diuretic by inhibiting the $\mathrm{Na}^{-} / \mathrm{K}^{-} / 2 \mathrm{Cl}^{-}$cotransporter in the ascending limb of the loop of Henle in the kidney. ${ }^{17}$ It achieves a high local concentration as it is concentrated within the kidney. It may be of interest that frusemide exerts its anti-asthma effect only when given by inhalation in relatively high doses (20-40 mg) and is not effective after oral administration in doses that cause diuresis. ${ }^{2}$ This suggests that relatively high local concentrations are required and that the target cell is superficially located within the airway. Bumetanide is a more potent loop diuretic and is a more potent inhibitor of the same cotransporter but it is not effective in the same challenges. ${ }^{511}$ Furthermore, the more potent diuretics piretanide and torasemide have less protective effect than frusemide. ${ }^{21318}$ This strongly suggests that the anti-asthma effect of inhaled frusemide is unrelated to its diuretic action. In addition other diuretics, including acetazolamide and amiloride, are either not very effective or are ineffective. ${ }^{+9}$ Frusemide reduces the epithelial potential difference and short circuit current in airways in vitro, suggesting that it may have a direct effect on airway epithelial cells. ${ }^{20}$ Nebulised frusemide, however, has no effect on nasal potential difference even though amiloride, which blocks sodium transport in the lumen, is effective. ${ }^{+}$

By analogy with sodium cromoglycate and nedocromil sodium, another possible mechanism of action of frusemide is an effect on inflammatory cells, including mast cells. Some of the indirect challenges inhibited by inhaled frusemide (including the early response to allergen, adenosine, hyperventilation, exercise, and fog) are believed to be mediated, at least in part, by release of mast cell mediators. Indeed, frusemide appears to inhibit the release of histamine and leukotrienes in passively sensitised human lung in vitro. ${ }^{21}$ In vivo inhaled frusemide inhibits the release of neutrophil chemotactic factor during fog induced bronchoconstriction, suggesting an inhibitory effect on the release of airway mediator in asthma. ${ }^{12}$ Furthermore, frusemide has an inhibitory action on mediator release from eosinophils in vitro, ${ }^{22}$ an effect that appears to be due to inhibition of $\mathrm{Cl}^{-}$transport. This may be consistent with the inhibitory effect of frusemide on the late response and on the early airway hyperresponsiveness following allergen challenge. ${ }^{89}$

Although the mechanism of action of cromones in asthma is still uncertain, there is evidence to suggest that they have effects on sensory nerve function; similar findings have been reported with frusemide. Both nedocromil sodium and frusemide modulate neuropeptide release from sensory nerves of guinea pig airways in vitro. ${ }^{1623}$ Frusemide also has a modulatory effect on cholinergic neural responses, which are not affected by mechanical removal of the epithelium and are therefore presumed to be direct neural effects. ${ }^{16}$ The protective effect of inhaled frusemide against metabisulphite induced bronchoconstriction in asthmatic patients provides supportive evidence that an effect on sensory nerves may be important. Further evidence is provided by the inhibitory effect of inhaled frusemide on cough induced by low chloride solutions and prostaglandin $\mathrm{F}_{2 \alpha}$ in normal volunteers. ${ }^{14-26}$ It is of interest that nedocromil sodium has an inhibitory effect on chloride transport in an isolated vagus nerve preparation, ${ }^{27}$ suggesting the possibility that frusemide and cromones have a common molecular mechanism of action which involves blockade of a particular type of chloride channel in sensory nerves.

\section{Role of prostaglandins}

The fact that frusemide enhances the synthesis of prostaglandin $\mathrm{E}_{2}$ in the kidney, which may affect renal blood flow, 2829 has suggested that inhibitory prostaglandins, perhaps released from airway epithelial cells, may mediate the protective effect of frusemide in some challenges. Support for this is provided by a recent study in which the cyclooxygenase inhibitor indomethacin appeared to reduce the protective effect of frusemide in exercise induced asthma. ${ }^{10}$ This is unlikely, however, as inhibitory prostaglandins released by frusemide should also be protective against directly acting bronchoconstrictors such as histamine and methacholine. Furthermore, another cyclooxygenase inhibitor (flurbiprofen) does not modulate the protective effect of frusemide in metabisulphite induced bronchoconstriction. ${ }^{30}$ Similarly, lysine aspirin potentiates rather than enhances the protective effect of inhaled frusemide in fog induced asthma. ${ }^{31}$ In addition, frusemide has an inhibitory action against certain cough challenges ${ }^{24-26}$ whereas if it released prostaglandin $E_{2}$ this would be expected to enhance cough challenge. ${ }^{32} 33$

\section{Clinical implications}

Although inhaled frusemide has a similar effectiveness to 
nedocromil sodium in bronchial challenge studies, it is not yet certain whether it has a useful anti-asthma effect in patients with asthma and studies with regular inhaled frusemide are currently under way. The protective effect of frusemide appears to be unrelated to its diuretic action and therefore there is a possibility that compounds that have a more potent anti-asthma effect but are devoid of diuretic activity may be discovered. The molecular mechanism of action of frusemide is still uncertain but it is possible that a particular type of chloride ion channel is blocked and that this channel-presumably in mast cells, other inflammatory cells, and sensory nerves-is also the target for cromones. This may give insight not only into the mode of action of cromones in asthma but also into the mechanisms of allergic inflammation itself, which may lead the way in the future to the development of more potent and longer lasting drugs with a safety margin as enviable as that of cromones. What started out as a curious observation has turned into an area of research well worth pursuing.

P J BARNES

Department of Thoracic Medicine, National Heart and Lung Institute, London SW3 $6 L Y$

Reprint requests to: Professor P J Barnes

1 Chung KF, Barnes PJ. Loop diuretics and asthma. Pulmonary Pharmacol 1992;5:1-7.

2 Bianco S, Vaghi A, Robuschi M, Vaghi A, Pasargiklian M. Prevention of exercise-induced bronchoconstriction by inhaled fruesemide. Lancet 1988;2:252-5.

3 Robuschi M, Cambaro G, Spagnotto S, Vaghi A, Bianco S. Inhaled furosemide is highly effective in preventing ultrasonically nebulised water bronchoconstriction. Pulmonary Pharmacol 1989;1:187-91.

4 Nichol GM, Alton EWFW, Nix A, Geddes DM, Chung KF, Barnes PJ. Effect of inhaled furosemide on metabisulfite and methacholine induced bronchoconstriction and nasal potential difference in asthmatic subjects. Am Rev Respir Dis 1990;142:576-80.

5 O'Connor BJ, Chung KF, Chen-Wordsell YM, Fuller RW, Barnes PJ. Effect of inhaled furosemide and bumetamide on adenosine $5^{\prime}$ monophosphate and sodium metabisulphite-induced bronchoconstriction. Am Rev Respir Dis 1991;143:1329-33.

6 Polosa R, Lau LCK, Holgate ST. Inhibition of adenosine 5'-monophosphate- and methacholine-induced bronchoconstriction in asthma by inhaled frusemide. Eur Respir F 1990;3:665-72.

7 Grubbe RE, Hopp R, Dave NK, Brennan B, Bewtra A, Townley R. Effect of inhaled fuosemide on the bronchial response to methacholine and cold-air hyperventilation challenges. F Allergy Clin Immunol 1990;85: 881-4.

8 Bianco S, Pieroni MG, Refini RM, Rottoli L, Sestini P. Protective effect of inhaled furosemide on allergen-induced early and late asthmatic reactions. N Engl ₹ Med 1989;321:1069-73.

9 Verdiani P, Stefania C, Baronti A, Bianco S. Effect of inhaled frusemide on the early response to antigen and subsequent change in airway reactivity in atopic patients. Thorax 1990;45:377-81.

10 Pavord ID, Wisniewski A, Tattersfield AE. Inhaled frusemide and exercise induced asthma: evidence of a role for inhibitory prostanoids. Thorax 1992;47:797-800.

11 Duggan CJ, Dixon CMS, Ind PW. Inhaled frusemide inhibits exercise induced asthma (EIA) but bumetamide does not [abstract]. Thorax 1990;45:798P

12 Moscato G, Dellabianca A, Falagiani I, Mistrello G, Rossi G, Rampulla C. Inhaled furosemide prevents both the bronchoconstriction and the increase in neutrophil chemotactic activity induced by ultrasonic "fog" of distilled water in asthmatics. Am Rev Respir Dis 1991;143:561-6.

13 Foresi A, Pelucchi A, Mastropasqua B, Cavigioli G, Earlesi RM, Marazzini L. Effect of inhaled fuurosemide and torasemide on bronchial responses to ultrasonically nebulized distilled water in asthmatic subjects. Am Rev Respir Dis 1992;146:364-8.

14 Stone RA, Yeo TC, Barnes PJ, Chung KF. Frusemide inhibits cough but not bronchoconstriction to prostaglandin $F_{2 \alpha}$ in patients with asthma [abstract]. Am Rev Respir Dis 1991;143:A548.

15 Knox AJ, Ajao P. Effect of frusemide on airway smooth muscle contractility in vitro. Thorax 1990;45:856-9.

16 Elwood W, Lötvall JO, Barnes PJ, Chung KF. Loop diuretics inhibit cholinergic and non-cholinergic nerves in guinea pig airways. $A m \operatorname{Rev}$ Respir Dis 1991;143:1340-4.

17 Haas M. Properties and diversity of $(\mathrm{Na}-\mathrm{K}-\mathrm{Cl})$ co-transporters. Annu Rev Physiol 1989;51:443-57.

18 Yeo CT, O'Connor BJ, Chen-Wordsell M, Barnes PJ, Chung KF Protective effects of loop diuretics, piretanide and frusemide, against sodium metabisulphite-induced bronchoconstriction in asthma. Eur Respir 71993.

19 O'Connor B, Yeo CT, Chen-Wordsell YM, Barnes PJ, Chung KF. Airway responses to sodium metabisulfite are inhibited by acetazolamide but not by amiloride. Eur Respir f 1991;4(Suppl 14):377S.

20 Welsh MJ. Inhibition of chloride secretion by furosemide in canine tracheal epithelium. F Membr Biol 1993;71:219-26.

21 Anderson SD, Wei HE, Temple DM. Inhibition by furosemide of inflammatory mediators from lung fragments [letter]. N Engl f Med 1991; 324:131.

22 Perkins R, Dent G, Chung KF, Barnes PJ. Effect of anion transport inhibitors and extracellular $\mathrm{Cl}$ - concentrations on eosinophil respiratory burst activity. Biochem Pharmacol 1992;107:481-8.

23 Verleden GM, Belvisi MG, Stretton CD, Barnes PJ. Nedocromil sodium modulates non-adrenergic non-cholinergic bronchoconstrictor nerves in guinea-pig airways in vitro. Am Rev Respir Dis 1991;143:114-18.

24 Ventresca GP, Nichol GM, Barnes PJ, Chung KF. Inhaled furosemide inhibits cough induced by low chloride content solutions but not by capsaicin. Am Rev Respir Dis 1990;142:143-6.

25 Stone RA, Barnes PJ, Chung KF. Frusemide and cough induced by low chloride content solution: duration of action [abstract]. Thorax 1991; 46:280-1P.

26 Ventresca P, Nichol GM, Barnes PJ, Chung KF. Effect of frusemide on the induction and potentiation of cough induced by prostaglandin $\mathrm{F}_{2 a}$ Br f Clin Pharmacol 1992;33:514-16.

27 Jackson DM, Pollard CE, Roberts SM. The effect of nedocromil sodium on the isolated rabbit vagus nerve. Eur $\mathcal{F}$ Pharmacol 1992;221: 175-8.

28 Mackay IG, Muir AL, Watson ML. Contribution of the prostaglandins to the systemic and renal vascular response to frusemide in man. $\mathrm{Br} \mathcal{f} \mathrm{Clin}$ Pharmacol 1984;17:513-19.

29 Miyanoshita A, Terada M, Endou H. Furosemide directly stimulates prostaglandin $\mathrm{E}_{2}$ production in the thick ascending limb of Henle's loop. I Pharmacol Exp Ther 1989;251:1155-9.

30 O'Connor BJ, Ridge SM, Barnes PJ, Chung KF. Inhibition of sodium metabisulphite-induced bronchoconstriction by frusemide in asthma: role of cyclooxygenase products. Thorax 1993;in press.

31 Bianco S, Vaghi A, Pieroni MG, et al. Potentiation of the protective effect of inhaled furosemide on the bronchial obstructive response to ultrasonically nebulised water by inhaled lysine acetylsalicylate [abstract]. Eur Respir f 1991;4(Suppl 14):606S.

32 Choudry NB, Fuller RW, Pride NB. Sensitivity of the human cough reflex: effect of inflammatory mediators prostaglandin $\mathrm{E}_{2}$, bradykinin and histamine. Am Rev Respir Dis 1989;140:137-41.

33 Nichol G, Nix A, Barnes PJ, Chung KF. Prostaglandin $F_{2 \mu}$ enhancement of capsaicin induced cough in man: modulation by $\beta_{2}$-adrenergic and anticholinergic drugs. Thorax 1990;45:694-8. 